Alla M. Kolomiiets, Ievgen V. Gromov, Dmytro I. Kolomiiets

Ukraine

Maya V.Suprun,

Tetiana V. Knysh,

Ukraine

Natalia Y. Hnatiuk

Ukraine

\title{
University Degree and Citizen Science: The Necessity for Promotion of the Latter and the Possibilities of Its Organization in the Teachers' Professional Training
}

DOI: 10.15804/tner.2021.64.2.14

\begin{abstract}
The article reveals the opportunities, types of organization and ways to use the citizen science results at the Pedagogical University. It's been proved that future teachers of different specialties have certain personal qualities that affect their training for scientific research activity. These qualities differ significantly. All in all, the average values of personal qualities indicators point out that future teachers can be quite successful in certain types of scientific research activities, considering their strong personal characteristics and improving the weak ones. It is proved that if the pedagogical university organizes the participation of students in citizen science, then they better develop the skills of self-organization and other personal qualities, essential for a modern teacher-researcher.
\end{abstract}

Keywords: citizen science, future teacher, scientific research activity, personal qualities of a scientist, teacher-researcher.

\section{Introduction}

In the modern era of informatization, humanity has accumulated such amounts of information that they do not have time not only to use them with 
benefits, but also to analyze them. Meanwhile, scientists from various fields understand that such arrays of information have a huge potential not only for new discoveries, but also to accelerate the development of certain areas of human activity and improve the quality of life in general. Who and how should analyze, systematize and offer to use the information accumulated by all citizens in practice? It is obvious that professional scientists will not be able to cope with this task. Other citizens should assist them. Awareness of the need to organize cooperation between scientists and ordinary citizens has led to the emergence of a new term «citizen science».

In the world in general and, in Australia, the USA, many Western European countries in particular, the concept of citizen science provides for research involving a wide range of volunteers, mainly amateurs, i.e. who have no prior training in science or education in general. However, as world experience shows, the use of research by ordinary citizens often helps scientists to achieve scientific goals more successfully than it would be possible without such involvement (Bonney et al., 2009), (Cooper et al., 2014). Furthermore, projects aimed at encouraging public participation in research as well as in science in general are common in many countries (Silvertown, 2009). Particular programs are designed specifically to engage schoolchildren or students (Bonney et al., 2014), (Burgess et al., 2017), (James-Creedon, 2016). The most recent example of important scientific research is the result of observations of schoolgirls from India, who discovered a new asteroid moving to the Earth. The discovery of the girls has already been confirmed at the University of Hawaii, and now it is waiting for confirmation of the asteroid orbit at NASA (https://edition.cnn. com/2020/07/28/india/india-schoolgirl-asteroid-intl-scli-scn/index.html).

Despite certain risks (obtaining incorrect or even false data), the work of many volunteers in civic scientific research is of great benefit to science in general, including saving finance, time and human resources (McCaffrey, 2005). However, in many countries the potential of this type of science is not yet fully exploited. Scholars explaining this refer to the lack of awareness of the public and representatives of institutional science about the types and possibilities of citizen science (Burgess et al., 2017). It is obvious that this type of scientific activity and the possibility of using its results require certain publicity events, which, in our opinion, could be organized by teachers (at the level of secondary schools) and lecturers (at the level of higher education institutions).

We should also mention a noteworthy investigation completed by the Polish reserachers Katarzyna Kącka, Bartłomiej Michalak, Joanna Piechowiak-Lamparska who made an attempt to define the factors which condition the level of the scientific activity and research productivity of the higher education institutions 
teachers (Kącka, Michalak \& Piechowiak-Lamparska, 2018). Therefore, we offer great opportunities for citizen science to be applied in the future teachers training.

Each teacher must be a researcher and develop scientific research skills of his or her students. Thus, the problem we are considering is relevant in four aspects:

- from the perspective of professional self-development: without the research component, the process of teacher self-development loses its integrity, flexibility, core essence;

- from the perspective of the educational process: ensuring subject-subject relations and co-creation of teacher and student is impossible without activating the skills of research activities of all participants in the educational process;

- from the perspective of future professional activity: research skills and methods of action are part of the basic competencies of the teacher, are an integral component of his or her professional activity;

- from the perspective of the university image: the scientific achievements of teachers and students of the university increase its rating, and the attractiveness for applicants.

\section{Analysis of recent researches}

The significant impact of citizen science on education and science in the universities is recognized worldwide. In scientific publications, the use of the phrase «citizen science» is growing rapidly (Kasperowski \& Kullenberg, 2019), (McCaffrey, 2005), (McKinley et al., 2015), (Ottinger, 2009), (Prainsack, 2014).

In addition to citizen science, the phrases crowd science, crowd-sourced science, civic science, networked science are also used. In general, the concept of citizen science involves the conduct of research by amateur volunteers and non-professional scientists through crowdsourcing and crowdfunding.

We appeal to the interpretation of citizen science, which defines it as the concept of involving the public in research conducted by scientists on the way to educational or scientific achievements (Bonney et al., 2009).

The contribution of citizen science to education has been demonstrated in many studies, but mainly in examples of solving environmental problems (Kasperowski \& Kullenberg, 2019), (National Advisory Council, 2018), (Silvertown, 2009). For instance, it has been shown that information on bird migration and climate change is largely based on citizen science data (Cooper et al., 2014).

The results of theoretical, methodological and applied research prove that the research approach in the training of future teachers ensures the development and 
functioning of pedagogical professional education at a qualitatively new level (Brovchak et al., 2018), (Kolomiiets et al., 2020), (Matiash \& Mykhailenko, 2020), (Klochko et al., 2020). However, neither in the theory nor in the practice of the Ukrainian pedagogical education the powerful potential of citizen science is of particular significance.

The aim of the article is to find out the possibilities, types of organization and ways of using civil science to improve the quality of professional training of future teachers; identify differences in the levels of personal readiness of future teachers of different specialties for the scientific research.

Research skills are a necessary component of readiness for professional activity in any field. An important professional characteristic is the ability of the individual to study. Priority is given to knowledge not acquired during training in HEE (high educational establishment), but the following personality characteristics: the ability to identify the problem, find ways to solve it, find non-standard methods of performing complex tasks, process large amounts of information, work in a team, negotiate, self-organization skills, analytical and strategic thinking, stress resistance, purposefulness. The following personal characteristics are the most essential for a pedagogue-researcher: a high level of theoretical knowledge, intelligence; purposefulness, self-organization, diligence, ability to work with significant amounts of information, persistence, responsibility, mental capacity, ability to discuss, ability to be eloquent. We offered students to assess these qualities.

Our long-term observations of the activities of students of different specialties gave grounds to suggest that there are some differences in the readiness of representatives of different specialties to scientific activity.

\section{Methodology of Research}

We used the following research methods: survey, observation, comparison, generalization and systematization of practical experience, methods of mathematic statistics (cluster, correlative, factor analyses). The survey was conducted in the period of five years among undergraduate students. It was offered to evaluate on a 5-point scale the available personal qualities indicated in the questionnaire. The survey results were processed using Microsoft Excel statistical analysis programs; 986 participants were involved in the experiment. Statistical data processing was as follows:

1. Determination of the average values of indicators as the arithmetic mean of all students in the group for certain specialties. 
2. Specification of the total values of indicators for each student and with the aim of determining the general level of readiness for scientific activities of students of different specialties.

3. Determination of maximum and minimum values of indicators for each specialty.

4. Calculation of values correlation coefficients of the corresponding indicators of readiness for scientific activity among students of different specialties.

\section{Research Results and Discussion}

Summarizing the results of the questionnaire before the experiment gave some interesting results. In particular, all students, regardless of their specialty, have the total value of ten indicators of readiness for scientific activity almost the same and it was in the range of $38-42$ points out of 50 maximum possible. The most important in each group was the indicator of «responsibility» (the average value in different groups varied between $4.05-4.35$ points), and the least important «self-organization» (in the range of $3.05-3.28$ points) (see table).

However, after the first year of the observation, it became clear that we could not compare the readiness for scientific activity of students in different specialties. In the results processing of self-assessment indicators, the correlation coefficients of numerical data for different groups of students were calculated. It was found that only the indicators of certain specialties correlate with each other. For example, future teachers of mathematics, physics, chemistry, biology and geography have quite similar results. In other specialties, the results on the same indicators, such as persistence or intellectual performance, were radically different.

Therefore, we were interested in longitudinal research, the data for which were able to be isolated from the general data set due to the fact that the research was conducted for several years in each specialty separately. According to the similarity of the results, we grouped students in the following research areas (clusters): science and mathematics - future teachers of mathematics, physics, chemistry, biology, geography $(\mathrm{SM})$, history - future teachers of history $(\mathrm{H})$, primary and preschool education - future preschool teachers and teachers of primary school (PPE), philology - future teachers of Ukrainian and foreign languages $(\mathrm{Ph})$, physical culture - future teachers of physical culture (PC). The average arithmetic values of indicators for individual scientific areas (specialties) are presented in table 1. 
Table 1. Average indicators values (particular personal qualities) in different scientific directions

\begin{tabular}{llccccc}
\hline \multirow{2}{*}{ № } & \multirow{2}{*}{ Personal qualities } & \multicolumn{4}{c}{ Scientific directions (specialties) } \\
\cline { 3 - 6 } & & SM & H & PPE & Ph & PC \\
\hline 1 & Level of knowledge & 3.98 & 3.75 & 3.85 & 3.75 & 3.61 \\
\hline 2 & Purposefulness & 4.15 & 3.45 & 4.08 & 3.42 & 4.12 \\
\hline 3 & Self-organization & 3.39 & 3.28 & 3.35 & 3.05 & 3.43 \\
\hline 4 & Diligence & 3.64 & 3.86 & 3.44 & 3.65 & 3.42 \\
\hline 5 & Work with information sources & 3.87 & 3.95 & 3.81 & 3.91 & 3.56 \\
\hline 6 & Persistence & 4.17 & 3.65 & 4.06 & 4.05 & 4.22 \\
\hline 7 & Responsibility & 4.26 & 4.05 & 4.35 & 4.24 & 4.24 \\
\hline 8 & Intellectual performance & 4.33 & 3.87 & 4.07 & 3.41 & 3.32 \\
\hline 9 & Ability to discuss & 3.46 & 3.87 & 3.81 & 3.78 & 3.67 \\
\hline 10 & Public speaking skills & 3.42 & 3.83 & 3.78 & 3.85 & 3.51 \\
\hline & Generalized average score by specialty & 3.87 & 3.73 & 3.86 & 3.71 & 3.71 \\
\hline & & & & & &
\end{tabular}

Despite the relatively identical arithmetic mean values of the generalized indicator of readiness for research activities on personal qualities, as it can be seen from the table, some indicators for students of different specialties are significantly different. For instance, students of natural sciences and mathematics have higher indicators of intelligence, purposefulness, intellectual performance, but their ability to discuss and the public speaking skills indicators are lower than these indicators among the students of other specialties. Persistence rates were highest among future teachers of physical education, diligence and the ability to discuss among historians. Future educators and primary school teachers have the greatest responsibility, and philologists are best prepared for public speaking.

To confirm the assumption concerning the existence of general differences between the students majoring in humanitarian and natural-mathematical specialties, similar surveys were conducted at three more higher education institutions: Lutsk Biotechnical Institute of International University of Science and Technology, the Department of Humanities and the Department of Natural-Mathematical Sciences of Volyn National University. The survey results confirmed our assumption that there are significant differences in the numerical indicators of the undergraduates' personal qualities depending on their specialization. It has been found out that continuous majoring in a certain specialty may become the factor which significantly determines the students' style of thinking and develops certain 
personal abilities. Thus, a future specialist's readiness for R\&D activity in certain indicators is conditioned by his/her profession specificity.

In general, the average values of personal qualities of the students representing four investigated higher education institutions (which are in the range of 3.71 - 3.87 points), indicate that Master's degree students can be quite successful in certain types of research, have their strong personal characteristics and improve the weak ones. Therefore, in order to train a teacher-researcher, it was decided to take appropriate measures aimed at increasing the level of their personal readiness for research activities.

The second part of the study was devoted to the process of formation of the necessary for research activities personal qualities of future teachers while studying at the university. We implemented this process in five stages (Table 2):

Table 2. Stages of personal qualities formation essential for scientific research activity

\begin{tabular}{|c|c|c|}
\hline Stages & Objective & Forms and methods \\
\hline I - diagnosis & $\begin{array}{l}\text { Identify the level of the necessary } \\
\text { qualities formation }\end{array}$ & Questionnaires, interviews \\
\hline II - motivation & $\begin{array}{l}\text { Formation of the stable motives for } \\
\text { scientific research }\end{array}$ & $\begin{array}{l}\text { Problem-based situation discussion, } \\
\text { case problem, dialogues, meetings } \\
\text { with leading scientists, involvement } \\
\text { in civil scientific research }\end{array}$ \\
\hline $\begin{array}{l}\text { III - prepara- } \\
\text { tion }\end{array}$ & $\begin{array}{l}\text { Development of the necessary quali- } \\
\text { ties for the research and the presenta- } \\
\text { tion of its results }\end{array}$ & $\begin{array}{l}\text { Visiting thesis defenses, analysis of } \\
\text { scientific problems, finding ways } \\
\text { to solve them, performing mini-re- } \\
\text { search }\end{array}$ \\
\hline IV - correction & $\begin{array}{l}\text { Improvement of the strengths and } \\
\text { strengthening the weaknesses of the } \\
\text { personality }\end{array}$ & $\begin{array}{l}\text { Mini-reports on the topic of the } \\
\text { thesis, self-analysis of the speech, } \\
\text { analysis of reports and publications } \\
\text { of other researchers }\end{array}$ \\
\hline $\begin{array}{l}\text { V - implemen- } \\
\text { tation }\end{array}$ & $\begin{array}{l}\text { Creating a situation of success to } \\
\text { develop a strong desire and personal } \\
\text { readiness for scientific activity }\end{array}$ & $\begin{array}{l}\text { Thesis defense, embarking on post- } \\
\text { graduate studies, writing scientific } \\
\text { articles }\end{array}$ \\
\hline
\end{tabular}

Taking into account the results of the survey, conducted in the first stage of research, we concluded that we need to involve students of pedagogical universities in citizen science from the first year of their study to increase the level of personal readiness of future teachers for research and improve certain indicators of such readiness. 
Participation in citizen science can be passive or active. In the first case, the student in the role of the subject fills out questionnaires, has various types of testing, and passes tests and so on. In case of active participation, the following types of scientific activity are possible:

- observation of natural objects or phenomena;

- work with archival records;

- usage of specialized computer programs for modeling virtual or studying real objects, etc.

In the education process we intensify the students' research activities in the following forms:

- delivering problem-based lectures that have a high degree of interactivity;

- performing the individual research tasks;

- solving problems in practical classes;

- conducting pedagogical traineeship at schools;

- writing and defending term papers and thesis.

Implementing the above-mentioned forms, we consider a range of requirements:

- maximum loading of the educational process with creative, interesting and cognitive situations;

- stimulating the scientific research activities, initiating the prospects of personal and professional growth;

- purposeful, systematic management of the educational process taking into account the strong personal qualities and needs of each student;

- organization of the educational process on the basis of problematic educational and scientific research tasks;

- active use of information and communication technologies and scientific databases to increase the efficiency of searching for scientific information and presenting the results of their own research;

- free choice of the research direction;

- monitoring of cognitive interests and research abilities of students;

- performance of interdisciplinary tasks that require the use of integrated knowledge.

The results that students can obtain in the course of interdisciplinary tasks in the form of citizen science, provide not only significant material for understanding the specifics of modern school, but also ensure the integration of pedagogical education with institutional research in the course, term papers, thesis (Kolomiiets et al., 2017). 
The organization of citizen science at the Vinnytsia Mykhailo Kotsiubynsky State Pedagogical University and the involvement of teachers and students in it made it possible to obtain results important for institutional science (http://vspu. edu.ua/science/new-style/students.php). We present some of the above-mentioned results.

All students of pedagogical specialties are involved in diagnosing their professional competence, which allows to identify possible deformations in time and to carry out further correction of personality in the process of professional self-development. The main focus is on developing the ability to determine the strategy of future pedagogical activities, use innovative pedagogical technologies, master the techniques of interpersonal communication, initiate and organize research and innovation projects, self-study and self-develop (Brovchak et al., 2018).

At the Department of Mathematics, a contest of methodical skills has been held for undergraduate students for several years in a row. The results of the survey of the participants of the contest before and after its holding showed an increase in the interest of the vast majority of students in methodological science, in future activities at school. Some students, having won this contest, decided on their own aspirations and intentions to study for a master's degree in the future of scientific research (Matiash \& Mykhailenko, 2020).

The effectiveness of the integrative use of digital models of circulatory dynamics and interactive teaching methods to improve the health competence of physical education teachers has been confirmed. Namely, there was a significant improvement in the results of the formation of knowledge of circulatory dynamics and critical thinking of physical education teachers (Klochko et al., 2020). Due to the participation of student-athletes in the experiment, the expediency of using methods to determine the athletic form of athletes in team sports during the training macrocycle has been scientifically substantiated (Kostiukevych et al., 2019).

The lecturers and students of the Department of Chemistry scientifically substantiated the feasibility of modern entrepreneurs to use bentonite clay as a natural sorbent capable of absorbing heavy metal ions to purify wastewater and improve its physicochemical and organoleptic indices by ion exchange and filtration properties. The environmental component in business is seen not as a barrier to development and unavoidable costs, but as an area of additional opportunities, a new means of increasing competitiveness through relatively low cost (Sakalova et al., 2019).

By involving master's students in an experiment in the study of certain disciplines in English the main factors that motivate future teachers to learn foreign languages were identified (Kolomiiets et al., 2020). 
Large-scale involvement of future teachers in passive and active participation in scientific activities over the past few years has contributed to a significant increase in the number of medal places in various contests of student research papers (Fig. 1) http://www.vspu.edu.ua/science/new-style/students.php).

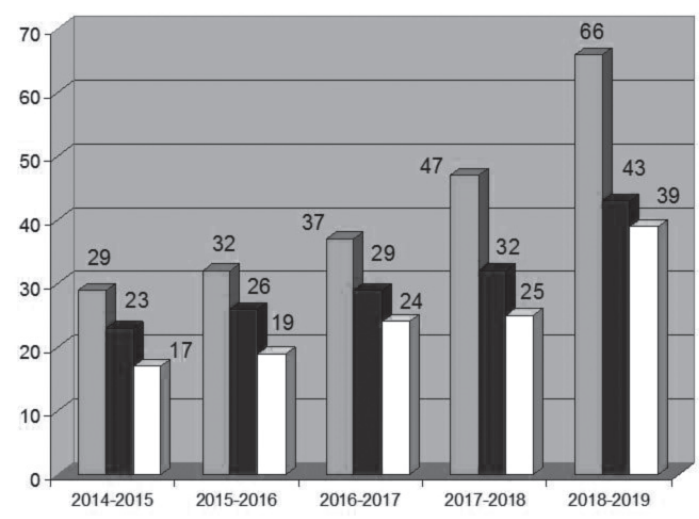

the number of submited works

- the amount of the invited students

$\square$ the amount of medal places

Figure 1. Increasing the activity and efficiency of participation in contest of student research papers

The figure demonstrates a direct linear relationship between the submitted applications for competitions and the number of victories. However, the victory of students is not the most important result of their involvement in scientific research activities. We fully agree with Barbara Prainsack (Prainsack, 2014: p.156) that for many students, being part of something useful, being publicly recognized in publications, or learning something new about a particular field of science is a sufficient incentive to participate in citizen science. For many future teachers, involvement in citizen science during the five years of study at the university has become a significant incentive to embark on postgraduate program, as indicated by the dynamics of the number of applications over the past 5 years (http://www. vspu.edu.ua/science/new-style/asp.php).

In general, the intensification of mass involvement of students not only in institutional but also in citizen science, as our practice shows, provides strengthening of integration of science and education (Kolomiiets et al., 2017), closer contact of pedagogical university with scientific institutions, development of partnership with enterprises and other economic entities in the region (Klochko et al., 2020), the university's participation in the implementation of scientific and technical 
policy at the regional level (Sakalova et al., 2019), expanding the participation of scientists and students in international scientific and educational programs (Denysyk et al. al., 2019; Kolomiiets et al., 2020).

Our observations showed that the active participation of students of the Pedagogical University in various types of citizen science for several years contributed to an increase in the number of those willing to obtain master's degree, and among master's program students the share of those, engaged in scientific activities in the future, is significantly increased (from $13.2 \%$ to $24.8 \%$ ).

\section{Conclusions}

Thus, despite some differences in the levels of personal readiness of future teachers of different specialties for research, citizen science at the Pedagogical University is one of the most effective methodological approaches to improve the quality of professional training of teachers, a means of integrating science and education, and a powerful tool for promoting scientific knowledge among young people and strengthening students' motivation for scientific research activity.

The main, most effective forms of intensification of research activities of students of pedagogical universities are defined as follows: interactive problem-based lectures that require analytical and critical thinking; performance of individual scientific-research tasks; solving practical problems that require scientific research; conducting a mini-experiment during practice in school; performance of term papers and thesis.

Personal qualities and skills formed by students while their study at the university, taking into account the basic conceptual provisions of civil science, form the personal and professional readiness of the future teacher to carry out innovative pedagogical activities in accordance with the principles of science, nature and culture. The teacher-researcher will always be interesting for students and will be able to form the relevant research personal qualities and skills.

\section{References}

Bonney, R., Cooper, C.B., Dickinson, J. et al. (2009) Citizen Science: A Developing Tool for Expanding Science. Knowledge and Scientific Literacy. BioScience, 59 (11), 977-984. Bonney, R., Shirk, J.L., Phillips, T.B. et al. (2014) Next Steps for Citizen Science. Science, $343,1436-1437$. 
Brovchak, L., Starovoit, L., \& Likhitska, L. (2018) Pedagogical Conditions for Creative and Artistic Development of Children of Senior Preschool Age by Means of Art. The New Educational Review, 52 (2), 206-217.

Burgess, H.K., DeBey, L.B., Froehlich, H.E., et al. (2017) The science of citizen science: Exploring barriers to use as a primary research tool. Biological Conservation, 208, 113-120.

Cooper, C.B., Shirk, J., \& Zuckerberg, B. (2014) The Invisible Prevalence of Citizen Science in Global Research: Migratory Birds and Climate Change. PLoS ONE, 9(9), e106508. https://doi.org/10.1371/journal.pone.0106508

Denysyk, G., Kolomiiets, A., Gromov, I., et al. (2019) International Scientific and Pedagogical Communication as a Constituent Part of the Tourism Activity. Ukrainian Geographical Journal, 4, 28-39.

Indian schoolgirls discover asteroid moving toward Earth. By Swati Gupta and Amy Woodyatt, CNN. Updated 1946 GMT (0346 HKT) July 28, 2020. Available at: https:// edition.cnn.com/2020/07/28/india/india-schoolgirl-asteroid-intl-scli-scn/index.html

James-Creedon, J. (2016) The Whole Truth. Citizen Science Community Resources. Available at: https://jackiejamescreedon.wordpress.com/

Kasperowski, D. \& Kullenberg, C. (2019) The many modes of citizen science. Science \& Technology Studies, 32(2), 2-7.

Kącka, K., Michalak, B., \& Piechowiak-Lamparska, J. (2018) Impact of Scholarly Publications and the Selected Socio-Demographic Factors. The New Educational Review, 52, $11-21$.

Klochko, O., Fedorets, V., Maliar, O., et al. (2020) The use of digital models of hemodynamics for the development of the $21^{\text {st }}$ century skills as a components of healthcare competence of the physical education teacher. E3S Web Conf., 166, 10033.

Kolomiiets, A., Gromov, I., Kolomiiets, L., et al. (2020) Work with Foreign Scientific Editions as an Effective Factor of Motivating Undergraduates to Improve Their Foreign Language Competency. The New Educational Review, 60, 96-107.

Kolomiiets, A., Kolomiiets, D., \& Gromov, I. (2017) Implementation of The Latest WorldClass Scientific Achievements in Training Process of Future Teachers. Science and Education, 8, 72-77.

Kostiukevych, V., Lazarenko, N., Shchepotina, N., et al. (2019) Management of athletic form in athletes practicing game sports over the course of training macrocycle. Journal of Physical Education and Sport, 19 (1), 28-34.

Matiash, O., \& Mykhailenko, L. (2020) Opportunities for Method Competence Development of Mathematics Teachers: The Role of Participation in Competitions with Colleagues. Universal Journal of Educational Research, 8 (3), 747-754.

McCaffrey, R.E. (2005) Using Citizen Science in Urban Bird Studies. Urban Habitats. Available at: http://www.urbanhabitats.org/v03n01/citizenscience_full.html

McKinley, D.C., Miller-Rushing, A.J., Ballard, H.L. et al. (2015) Investing in Citizen Science Can Improve Natural Resource Management and Environmental Protection. Issues in Ecology, 19, 1-27. 
National Advisory Council for Environmental Policy and Technology (2018). Information to Action: Strengthening EPA Citizen Science Partnerships for Environmental Protection. Report for the Environmental Protection Agency. Report no. 220-R-18-001.

Ottinger, G. (2009) Buckets of Resistance: Standards and the Effectiveness of Citizen Science. Science, Technology and Human Values, 35 (2), 244-270.

Prainsack, B. (2014) Understanding Participation: The 'citizen science' of genetics. In: Prainsack, B., Werner-Felmayer G., \& Schicktanz, G. (eds) Genetics as Social Practice. Farnham: Ashgate, pp. 147-164.

Sakalova, H., Malovanyy, M., Vasylinycz, T., et al. (2019) Cleaning of Effluents from Ions of Heavy Metals as Display of Environmentally Responsible Activity of Modern Businessman. Journal of Ecological Engineering, 20 (4), 167-176.

Silvertown, J. (2009). A New Dawn for Citizen Science. Trends in Ecology \& Evolution, 24 (9), 467-471. 